\title{
Esthetic prosthesis for a patient with the maxillary diastema: a case report
}

\author{
Jae-Ho Park1, Hyeran Kim¹, Kwi-Dug Yun', Jin-Ho Shin², Hyun-Pil Lim* \\ 'Department of Prosthodontics, School of Dentistry, Chonnam National University, Gwangju, Republic of Korea \\ ${ }^{2}$ Mir Dental Hospital, Daegu, Republic of Korea
}

In the treatment of esthetically important areas such as maxillary anterior teeth, they should be corresponded with surrounding tissues, and shape of the smile line, soft tissue, and hard tissue, also the anatomical shape and proportion of the teeth should be considered as well. Esthetic analysis includes facial analysis which evaluates the proper parallelism between the occlusal plane and the horizontal reference line, dentolabial analysis which assesses the position of the incisal edge and the coherence between the occlusal plane and the commissural line, tooth analysis which evaluates not only esthetics but also morphology and appearance for proper function, and gingival analysis which forms ideal outline of gingival margins. A maxillary anterior diastema can be esthetically restored through the systematic diagnostic approach and treatment planning, and orthodontic, prosthetic, and conservative treatment can be applied for the treatment. (J Dent Rehabil Appl Sci 2017;33(4):314-20)

Key words: esthetic analysis; maxillary anterior diastema; prosthetic treatment

\begin{abstract}
서론
환자의 미소를 심미적으로 개선시켜 주기 위해서 상악 전치부는 매우 중요하며 다양한 구도 속에서 체계적인 진단 및 치료과정을 통해 수복물을 제작해야 한다. ${ }^{1}$ 안면 분석, 치아-입술 분석, 치아 분석, 치은 분석 등을 통해 전 치부 심미 보철 치료 시 환자마다 개별적으로 고려해야 할 사항에 대한 접근이 가능하다. ${ }^{2,3}$

안면 분석은 전체 안면을 구성하는 요소들을 평가하는 것으로 눈, 코, 턱 및 입술 위치에 대한 분석을 포함해서 환자를 정면과 측면에서 관찰하는 것이 기준점과 기준선 을 확립하는 데 도움을 준다. 치아-입술 분석은 절치 절

연부의 정확한 위치 및 적절한 절치부와 치아 길이를 재 설정하고 교합 평면과 구각선 사이의 적절하고 조화로운 지침을 제공하기 위함이다. 치아 분석은 만족스러운 심 미성뿐만 아니라 올바르게 기능할 수 있도록 치아의 적 절한 형태와 외형을 수복하기 위함이다. 치은 분석은 수 복물의 적절한 생물학적 통합을 유지하면서 치은변연의 이상적인 윤곽을 만들기 위함이다. ${ }^{2}$

본 증례는 상악 전치부 치간이개를 가진 환자에서 다 양한 심미 분석 후 고정성 보철물로 수복하여 심미적, 기 능적 면에서 만족할 만한 결과를 얻었기에 보고하는 바 이다. 


\section{증례보고}

본 증례의 환자는 48 세 남환으로 상악 전치부 공간을 포함해서 전반적인 보철치료를 주소로 내원하였으며 특 이할 만한 외과적 병력은 없었다. 진단을 위하여 파노라 마 방사선 사진 촬영 및 임상검사를 시행하였다(Fig. 1, 2). \#11, 12, 13, 14, 21 사이에 치간이개가 관찰되었으며 \#16, 27은 상실된 상태였다. \#24=26은 3본 금속도재관, \#47은 금관으로 수복된 상태였으며 \#26, 47 치아에서 는 깊은 치주낭과 2도의 동요도가 관찰되었다. \#31, 32, 41,42 치아에서는 2 도의 동요도와 총생이 관찰되었으며 \#35=37은 3본 금속도재관으로 수복된 상태 였으며 부 적절한 변연과 \#35 치아에서 우식이 관찰되었다. 전반적 인 치석 침착과 치주 질환이 이행된 상태였다.

교정치료에 대한 환자의 거부로 인하여 보철적인 방법 으로 수복하기로 결정하고 치료계획을 수립하였다. 예 후가 불량할 것으로 예상되는 \#26, 31, 32, 41, 42, 47 치 아를 발치하고 전반적인 치주 치료 이후에 \#25, 27, 47 에 임플란트를 식립하고 단일 구조 지르코니아를 이용하 여 \#14, 24 single crown, \#12-11-21-22 4 unit splinted

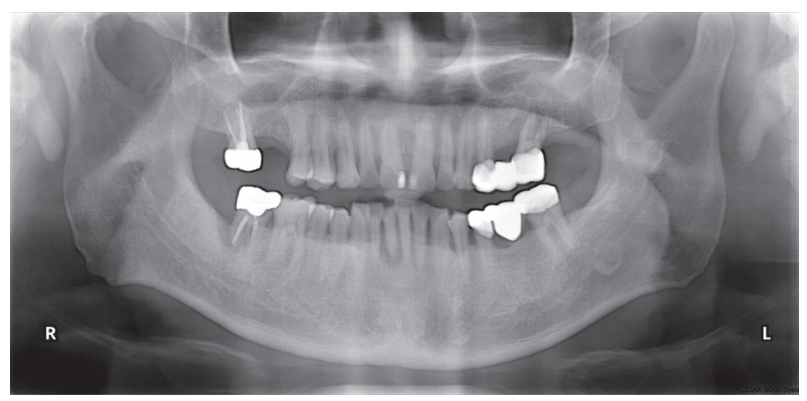

Fig. 1. Initial panoramic radiograph. crown, $\# 35=373$ unit bridge, $\# 33====436$ unit bridge 수복을 결정하였다.

심미적인 전치부 수복을 위하여 모형분석과 심미분석 을 진행하였다. Bolton의 치아비율 분석은 상악 전치의 크기에 대한 하악 전치의 크기의 비율을 결정하는 방법 으로서 교정 치료 이후에 얻어질 수평피개와 수직피개 관 계를 예측 할 수 있다. Bolton의 전방 치아 비율은 $84.8 \%$ 로 이상적 비율인 $77.2 \%$ 보다 크므로 상악 전치의 크기 가 작다는 것을 알 수 있다. 치궁 부조화는 상악 치궁에 서 -2.3 , 하악 치궁에서 +4.1 정도이다.

심미 분석은 안면, 치아-입술, 치아, 치은 분석 순으로 진행하였다. 안면 분석에서 동공간선과 교합평면 그리고 정중선은 비교적 일치 하였으며 안면비율에서 심각한 부 조화를 보이지 않았다. 미간, subnasale, 턱끝으로 구성된 안모의 세 기준점으로 형성되는 각도로 정의 되는 측모 는 정상 범위 $\left(170^{\circ}\right)$ 에 속해 있었다. 한국인의 경우 정상 적인 측모의 기준은 상순은 $1 \mathrm{~mm}$ 후방, 하순은 살짝 닿 는 정도 이며 환자의 경우 상순이 다소 튀어 나온 양상이 었다. 비순각은 정상범주(남성, $90-95^{\circ}$ )에 속해 있었다 (Fig. 3). 치아-입술 분석에서 상악 치아 절단면과 하순의
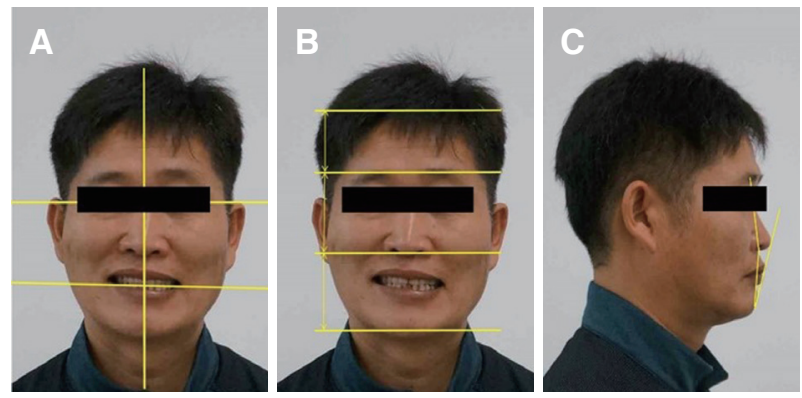

Fig. 3. Initial extra-oral photographs. (A) Interpupillary line, commissural line, midline, (B) Facial proportion, (C) Profile, E-line.
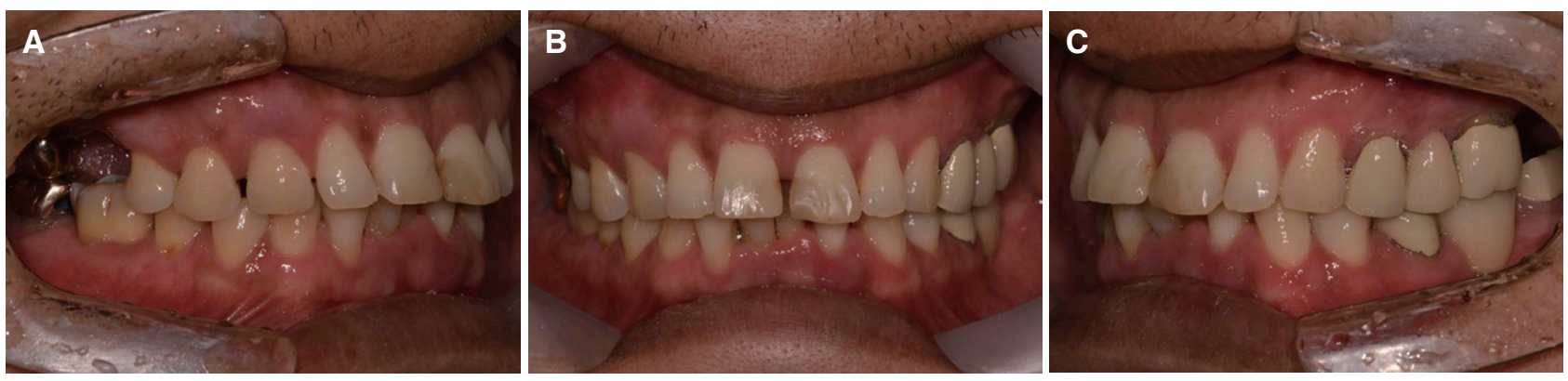

Fig. 2. Initial intraoral photographs. (A) Right lateral view, (B) Frontal view, (C) Left lateral view. 
곡선과 관련있는 미소선은 미소시 전치부가 $75-100 \%$ 노출되는 평균적인 미소선을 가지고 있었다. 치아 분석 은 상악 대 하악 절치간선, 상악 전치의 치축 경사, 전치 부 순면 폭과 길이의 비율 및 치아간 비율을 분석 하였 다. 상악과 하악의 절치간선은 좌측으로 $1 \mathrm{~mm}$ 편위되 어 있었으며 치축 경사 비교적 정상적인 경사를 보여주었 다(Fig. 4). 치은분석에서 불규칙한 치은연 정점(gingival zenith)과 두꺼운 치주조직의 생물학적 형태를 나타낸다 (Fig. 4). 이상적인 전치부 치아의 폭 대 길이의 비율과 치 아간 비율을 참고하여 진단납형을 제작하였다(Fig. 5).
방사선 스텐트를 이용하여 컴퓨터 단층 사진을 촬영한 후, 수술 스텐트로 전환하여 \#25, 27, 47 위치에 고정체 (USII SA $4 \times 11.5,5.0 \times 10,4.5 \times 10$; Osstem implant Corp, Seoul, Korea)를 식립 하였다. 임플란트 식립 5개 월 후에 지대치를 삭제 후에 임시 보철물을 제작 하였다. 임플란트 부위는 맞춤형 지대주 제작 및 연결하여 제작 하였다(Fig. 6). 2개월 동안 임시 보철물 상태로 불편감 없이 잘 적응 하였으며 기능 및 심미적으로 문제점이 발 견되지 않았다. 임시 보철물 상태에서 체크바이트를 채 득하였으며 전방유도를 재현하기 위해 개인 전방 유도판
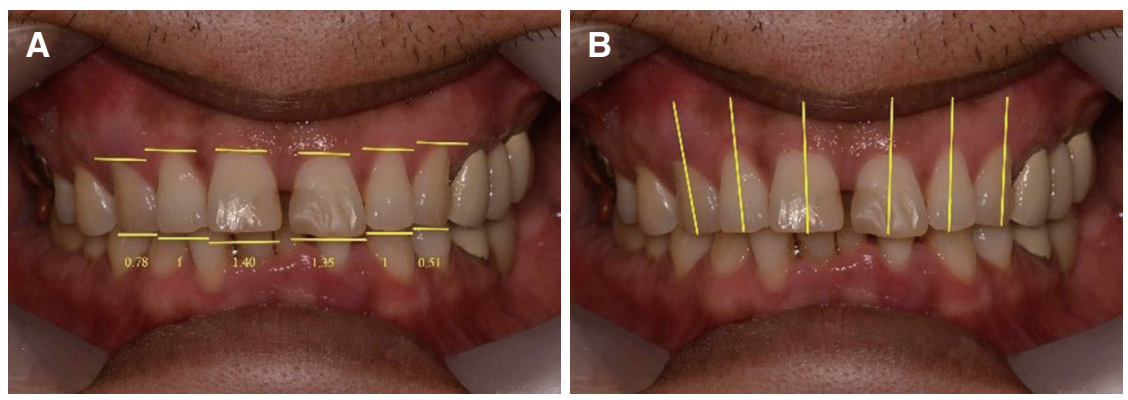

Fig. 4. Analysis of tooth and gingiva. (A) Tooth-to-tooth proportion, gingival zenith, (B) Axial inclination.
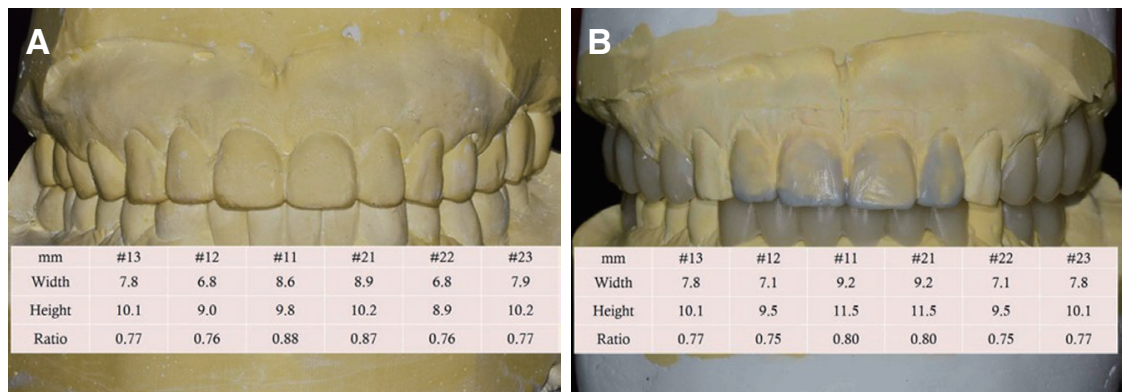

Fig. 5. Model analysis. (A) Analysis of diagnostic model, (B) Diagnostic wax-up in diagnostic model (Application of ideal teeth width/length ratio $75-80 \%)$.
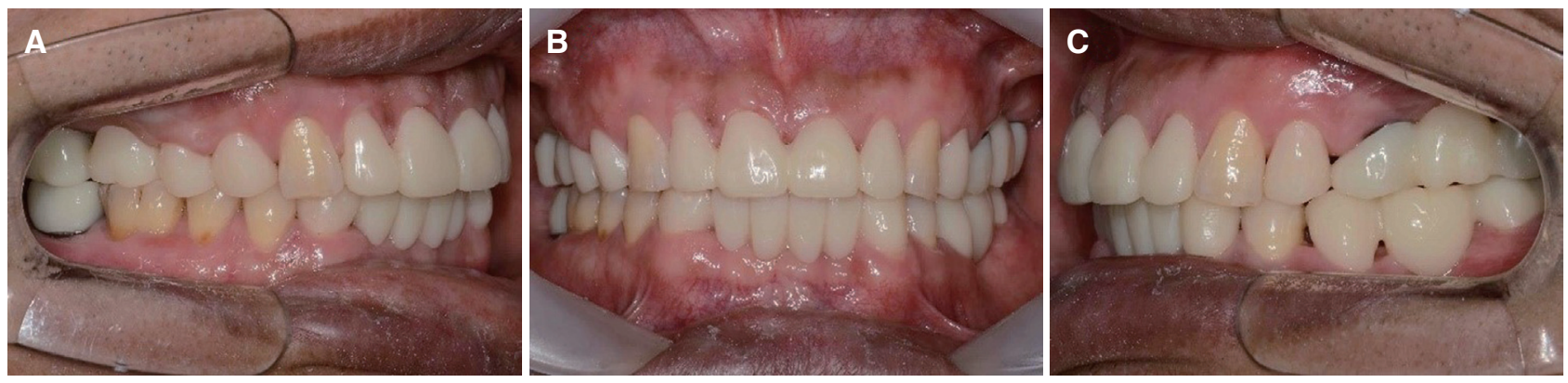

Fig. 6. Provisional restoration. (A) Right lateral view, (B) Frontal view, (C) Left lateral view. 

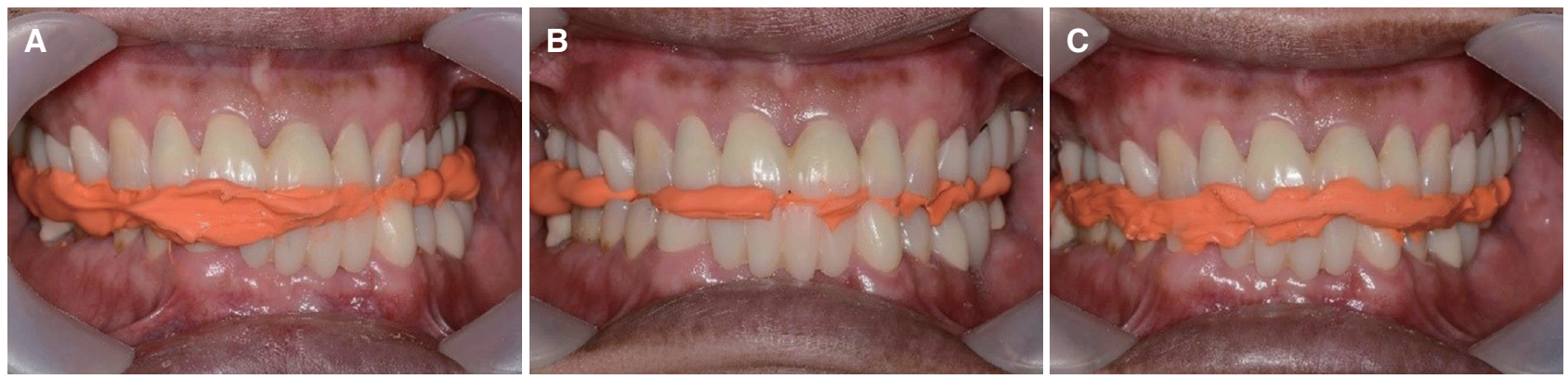

Fig. 7. Checkbite registration. (A) Left lateral, (B) Protrusive, (C) Right lateral.
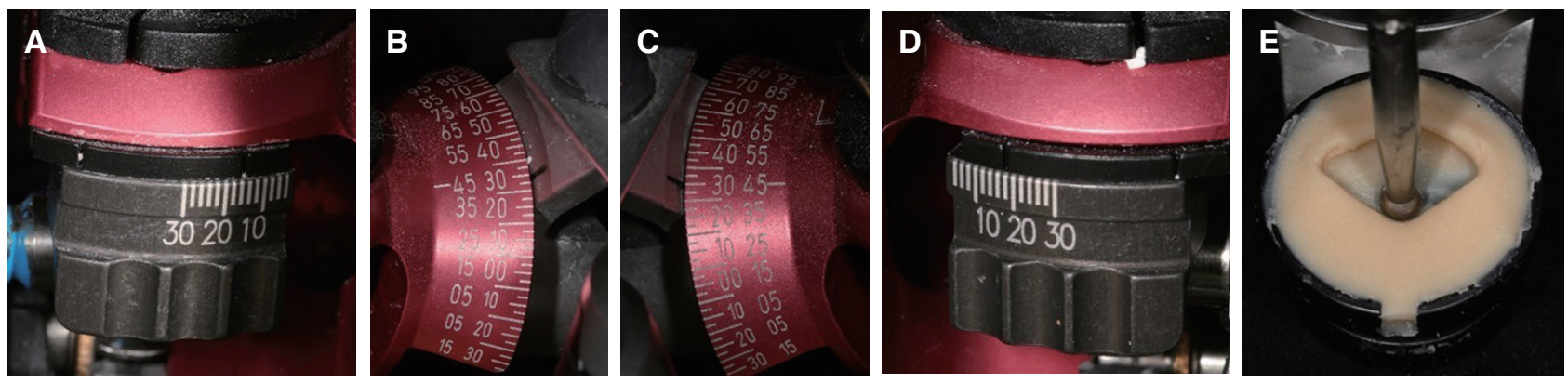

Fig. 8. (A) Left sagittal condylar angle adjustment, (B) and (C) Protrusive sagittal condylar angle adjustment, (D) Right sagittal condylar angle adjustment, (E) Customized incisal guide table.
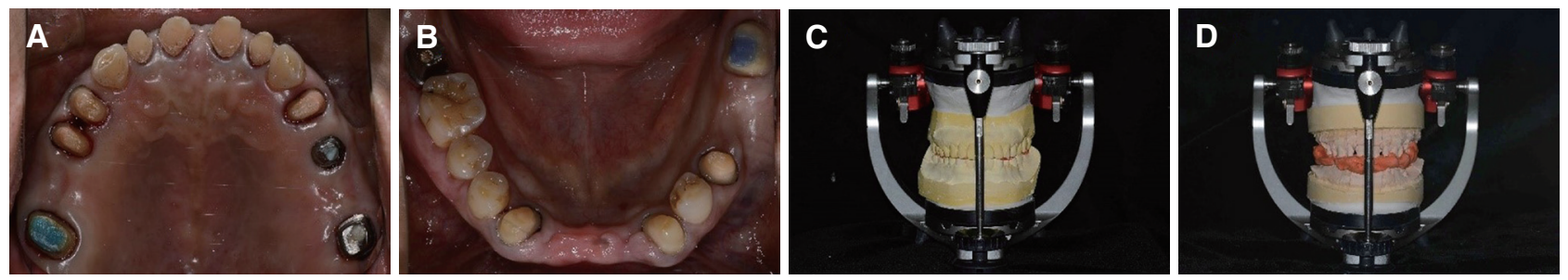

Fig. 9. (A) and (B) Final impression, (C) and (D) Cross mounting of casts.
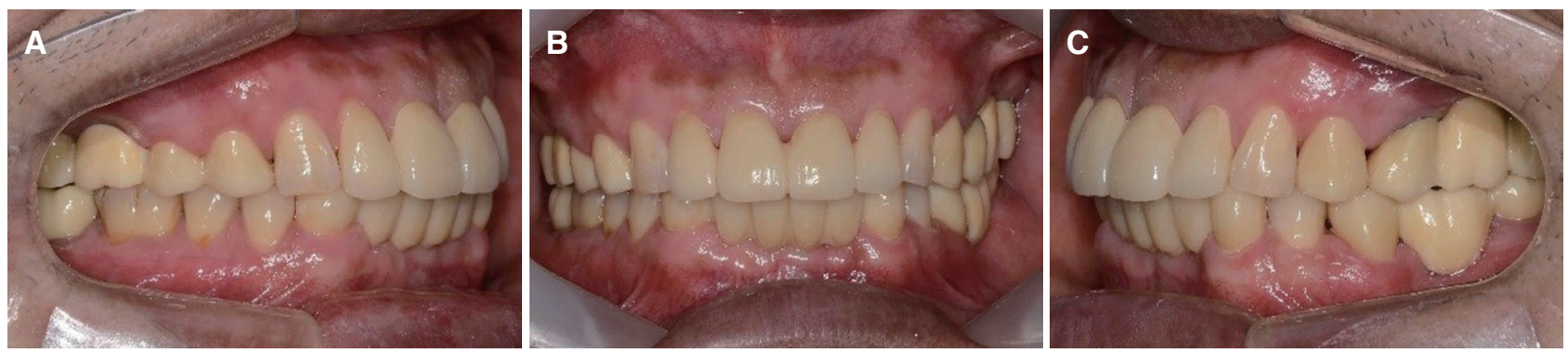

Fig. 10. Definitive restoration. (A) Right lateral view, (B) Frontal view, (C) Left lateral view.

을 제작하여 교합기에 반영하였다(Fig. 7,8 ). 최종 치아 형성을 하고 실리콘 인상재(Honigum, DMG, Hamburg, Germany)로 정밀 인상을 채득하여 작업모형을 제작하 고 cross-mounting하여 죄종 주모형을 교합기에 부착 하 였다(Fig. 9). 단일 구조 지르코니아를 이용하여 최종 보
철물을 제작하였으며 교합조정 이후에 레진 시멘트(RelyX U200, 3M ESPE, St. Paul, USA)를 이용하여 최종 합착하였다(Fig. 10). 보철물 장착 후 약 6개월간의 임상 적, 방사선학적 검사 결과 기능 및 심미적으로 만족할 만 한 결과를 얻을 수 있었다(Fig. 11). 

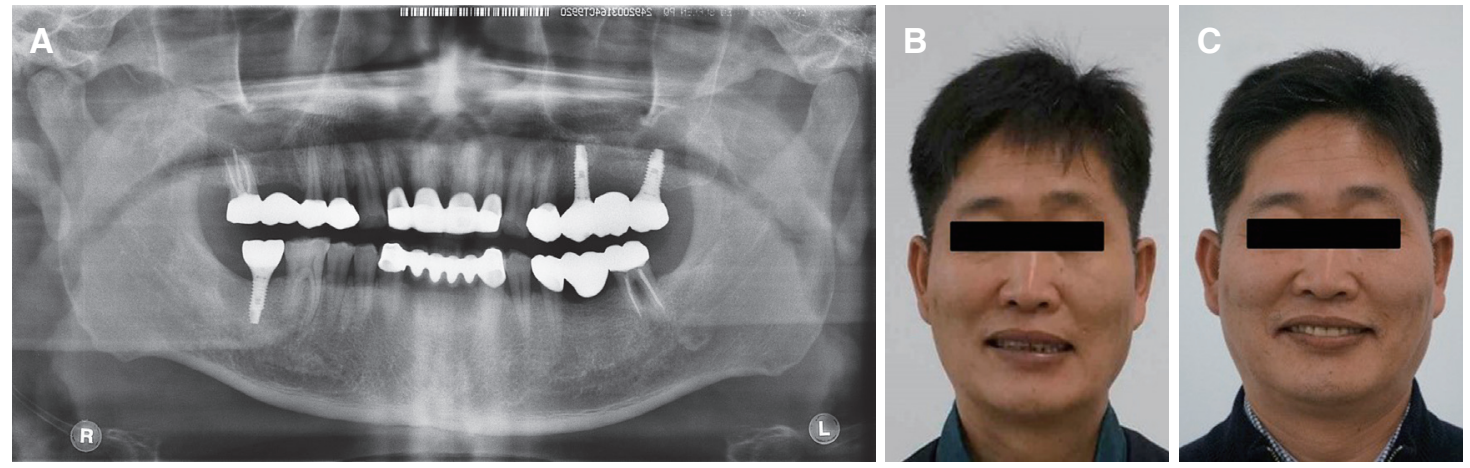

Fig. 11. (A) Panoramic radiographic after treatment, (B) Extra-oral photographs at initial visit, (C) Extra-oral photographs after treatment.

\section{고찰}

심미적인 치과 치료의 목표는 환자의 심미적인 미소를 되찾아주는 것이고, 치아와 입술과의 관계, 미소시 치아 의 노출 정도, 치아 주위 연조직의 변화, 연령 증가에 따 른 치아 형태와 안면의 변화등 치아와 미소의 기하학적 인 연관성을 밝히려는 많은 연구들이 있었다. ${ }^{410}$

첫째로 안면 분석에서, 동공간선은 눈의 중심을 관통 하는 직선으로 수평면과 평행할때 올바른 안면분석을 위 한 기준선이 된다. ${ }^{2}$ 이상적으로 상악 전치의 절단연과 구 각선은 동공간선과 평행하며 안모의 정중선과 수직이 다. ${ }^{10}$ 본 증례에서는 상악 전치의 절단연과 구각선이 안 모의 수평선과 이상적인 조화가 부족한 것으로 판단되어 안궁 이전을 하였으며 안궁과 동공간선을 일치하게 배 열하여 이러한 부조화를 줄이려 하였다. 측모 분석에서, Rickett's E-plane은 서양인 기준으로 상순과 $4 \mathrm{~mm}$, 하 순과 $2 \mathrm{~mm}$ 떨어진 것을 이상적으로 생각되며 비순각은 남성의 경우 $90^{\circ}-95^{\circ}$, 여성의 경우 $100^{\circ}-105^{\circ}$ 를 정상 범위로 보고된다. ${ }^{10}$ 본 증례에서는 상순이 다소 튀어 나 온 양상이었으며 비순각은 정상 범주에 속해 있었다.

둘째로 치아-입술 분석에서 상악 전치부 보철 치료시 심미적인 미소선을 항상 고려해야 한다. 미소선은 웃는 동안 보이는 전치부의 노출 정도는 평가하는 것으로 전 상방부의 치아와 치은의 노출 정도를 기준으로 낮은, 평 균적인, 높은 미소선의 세 가지 형태로 분류할 수 있다. ${ }^{11}$ 낮은 미소선은 전치의 $75 \%$ 이하가 노출되며, 평균적인 미소선은 $75-100 \%$ 의 전치부가 노출되며 치간부 치은 유두가 드러나는 상태를 말한다. 높은 미소선은 웃을 때 전치부가 완전히 드러나며, 치은부도 보이는 경우이다. 본 증례에서는 평균적인 미소선을 보여주었다.
셋째로 치아 분석에서, 상악 대 하악 절치간선은 대부 분의 사람들은 안면의 중심선과 상악의 절치 간선이 일 치하지만 상악의 절치 간선과 하악의 절치간선 사이가 일치하는 경우는 훨씬 드물며 약 $25 \%$ 인구에서 나타난 다. ${ }^{2}$ 정중선을 기준으로 전치의 치축은 보통 절단연은 근 심측에 위치하고 치경부쪽은 원심측에 위치한다. ${ }^{13}$ 전치 부의 치축 경사는 치아의 거울상과 대칭성을 형성하는데 있어서 핵심적인 역할을 한다. 본 증례에서는 상악과 하 악의 절치간선은 좌측으로 $1 \mathrm{~mm}$ 편위되어 있었으며 치 축 경사 비교적 정상적인 경사를 보여주었다. 상악 중절 치의 폭/길이 비율이 비정상적이었으며 중절치에서 대칭 성이 이루어 지지 않았다. 이에 따라 정상적인 비율(75 $80 \%$ )을 고려하여 진단 납형을 시행하였으며 최종 수복 물에 반영하여 길이를 결정하였다.

네 번째로 치은 분석에서, 치은연 정점은 치은 외형의 최근단 점으로 상악 치아에서 일반적으로 치아 장축에 대해 원심쪽에 위치 한다. ${ }^{14}$ 상악 전치 치은선은 절단연과 평행을 이뤄야 하며 좌우 대칭이다. ${ }^{15}$ 본 증례에서 치은연 정점 및 치은선이 불규칙한 것을 확인 할 수 있었으며 이 상적인 치아 폭/길이 비율을 적용하여 진단 납형모형을 제작하여 이를 최종 보철물에 적용하여 치은연 정점 및 치은선의 위치를 개선하였다.

\section{결론}

본 증례는 상악 전치부 치간이개를 가진 환자에서 심 미성에 영향을 미칠 수 있는 몇 가지 기준에 대한 분석과 평가 후 고정성 보철물로 수복하여 심미적, 기능적 면에 서 만족할 만한 결과를 얻게 되었다. 장기적인 유지 및 관 리를 위해 주기적인 내원이 필요하리라 사료된다. 


\section{ORCID}

Jae-Ho Park https://orcid.org/0000-0002-8737-7470

Hyeran Kim https://orcid.org/0000-0002-2992-5985

Kwi-Dug Yun https://orcid.org/0000-0002-2965-3967

Jin-Ho Shin https://orcid.org/0000-0003-2072-0614

Hyun-Pil Lim https://orcid.org/0000-0001-5586-1404

\section{References}

1. Pinto RC, Chambrone L, Colombini BL, Ishikiriama SK, Britto IM, Romito GA. Minimally invasive esthetic therapy: a case report describing the advantages of a multidisciplinary approach. Quintessence Int 2013;44:385-91.

2. Fradeani M. Esthetic rehabilitation in fixed prosthodontics. Volume 1. Esthetic analysis: a systematic approach to prosthetic treatment. Chicago; Quintessence; 2004. p. 16-31.

3. Raj V. Esthetic paradigms in the interdisciplinary management of maxillary anterior dentition-a review. J Esthet Restor Dent 2013;25:295-304.

4. Miller CJ. The smile line as a guide to anterior esthetics. Dent Clin North Am 1989;33:157-64.
5. Burstone CJ. Lip posture and its significance in treatment planning. Am J Orthod 1967;53:262-84.

6. Lombardi RE. Factors mediating against excellence in dental esthetics. J Prothet Dent 1977;38:243-8.

7. Ricketts RM. Esthetics, environment, and the law of lip relation. Am J Orthod 1968;54:272-89.

8. Rufenacht CR. Fundamentals of esthetics. Chicago; Quintessence Publishing Co. Inc.; 1990. p. 67-77.

9. Dong JK, Jin TH, Cho HW, Oh SC. The esthetics of the smile: a review of some recent studies. Int J Prosthodont 1999;12:9-19.

10. Ahmad I. Anterior dental aesthetics: facial perspective. Br Dent J 2005;199:15-21.

11. Tjan AH, Miller GD. The JG. Some esthetic factors in a smile. J Prosthet Dent 1984;51:24-8.

12. Miller EL, Bodden WR Jr, Jamison HC. A study of the relationship of the dental midline to the facial median line. J Prosthet Dent 1979;41:657-60.

13. Matthews TG. The anatomy of a smile. J Prosthet Dent 1978;39:128-34.

14. Wheeler RC. Complete crown form and the periodontium. J Prosthet Dent 1961;11:722-34.

15. Ahmad I. Anterior dental aesthetics: gingival perspective. Br Dent J 2005;199:195-202. 


\section{상악의 치간이개를 가진 환자에서의 심미보철 수복 증례}

\section{박재호 ${ }^{1}$, 김혜란 ${ }^{1}$, 윤귀덕 $^{1}$, 신진호 ${ }^{2}$, 임현필 ${ }^{1 *}$}

${ }^{1}$ 전남대학교 치의학전문대학원 보철학교실

${ }^{2}$ 미르치과병원

상악 전치부 같은 심미성이 요구되는 부위의 치료 시에는 주위조직과 조화를 이루며 미소선, 연조직 및 경조직의 형태뿐 아니라 치아의 해부학적 형태와 비율을 고려하여야 한다. 심미분석은 교합평면과 수평적 기준선간의 적절한 평행성을 평 가하는 안면분석, 절치 절연부의 위치와 교합평면과 구각선 사이의 조화로움을 평가하는 치아입술분석, 심미성뿐만 아니 라 적절한 기능을 위한 형태와 외형을 평가하는 치아분석, 치은 변연의 이상적인 윤곽을 형성하는 치은분석 등의 방법이 있다. 상악의 치간 이개는 체계적인 진단과 치료 계획을 통해서 심미적으로 수복할 수 있으며 교정, 보철, 보존적인 치료 방법이 사용될 수 있다.

(구강회복응용과학지 2017;33(4):314-20)

주요어: 심미분석; 상악의 치간 이개; 보철 치료 